\title{
PROFESSIONAL EDUCATION AS CATALYZER OF LOCAL DEVELOPMENT WITHIN THE CONTEXT OF COOPERATION NETWORKS IN CLUSTERS
}

\author{
Eduardo Dias Leite \\ Universitat Jaume I (UJI), Spain \\ Instituto Federal de Brasília, Brazil \\ E-mail: eduardodiasleite@ifb.edu.br \\ F. Xavier Molina-Morales \\ Universitat Jaume I (UJI), Spain \\ E-mail: xaiver.molina@emp.uji.es \\ Edgar Reyes Júnior \\ University of Brasilia (UnB), Brazil \\ E-mail: prof.edreyes@gmail.com
}

Submission: $12 / 04 / 2016$

Accept: 30/04/2016

\section{ABSTRACT}

Professional training, with knowledge spreading, promotes the fruitful actions for local development within the context of networks among organizations or clusters that constitute an organizational form able to be identified in several productive and innovative sectors. In the training for human resources, diverse educational and training actors seek to connect knowledge offer to local economical need. This article aims to describe the professional education in Brazil, in the scope of networks present in clusters which cooperate for local development, based on the main Brazilian economical activities, with a focus on the Federal District. For the development of this research, concerning the methodological aspects, the research was descriptive and for data collection documentary and bibliographic resources were used, on the basis of an analysis on the Pesquisa Nacional por Amostra de Domicilio, from IBGE, with the aid of SPSS program. The results highlight the main activities that need labor force in the Federal District and compare with what is really being offered in Brazil, whose service sector shows higher relevance. 
Keywords: professional education, local development, cooperation, interorganizational networks

This research was supported by "CAPES Foundation, Ministry of Education of Brazil".

\section{INTRODUCTION}

The professional education has shown itself as a relevant tool for the consolidation of the regional development, whose corporate training is provided with a network of institutions which Interact with several productive segments. Participation in a network leads to commitment and the sharing of responsibilities within that segment, so that there is complementarity between the various participants of that segment.

The basis for this statement is the fact that the complementarity of assets leads to a process of changes over time, which decreases the asymmetry of information and generates confidence, at the same time in which inhibits opportunistic behavior that would result in another type of economy other than transaction cost Williamson (1991).

However, in order to feature a productive arrangement, a cluster of enterprises must follow the requirements: physical proximity, working together, some kind of productive specialization, cooperation and confidence among its members. In addition to these factors, its success commonly explained from joints with institutions, such as universities, banks, technological institutes, support services to production and management. This template is associated with the idea of the network, in which there is a great power of interconnection between producers, consumers, suppliers and institutions Zapata, Amorim and Arns (2007).

An economic growth much more accentuated in peripheral regions has been observed in Brazil over the last decade, which featured a gradual internalization process of the Brazilian economic activity. In this context, according to Castanhar (2006), this shift of economic activity to the interior of the country was associated to the dynamism of productive agglomerations or local productive arrangements (APLs) formed between micro, small and medium-sized enterprises. Such agglomerations of enterprises would present reasonable degree of interior coordination among themselves and between them and other public or private institutions. 
DOI: 10.14807/ijmp.v7i3.472

This article aims to describe the professional education in Brazil, in the scope of networks inside clusters which cooperate to local development, based on the main Brazilian economical activities, emphasizing the Federal District. Thus, there is a new line of study, highlighting the spread of applied knowledge, in the existing clusters, in view of the importance of their training as generator of skilled labor, taking into account a larger number of people in the region and promoting a more sustainable development, when comparing with the existence of a major industry exerting the same role.

Thus, in the structure of this article, in addition to this introduction, the first topic of theoretical foundation discusses, briefly, the concept of networks of enterprises in the context of territorial settlements of enterprises, i.e. of cooperation networks related to the public policies, to then start the discussion that involves professional education as influencer of local development. In the following topics, the methodology used at work, the analysis and discussion of the results and conclusions are described.

\section{LITERATURE REVIEW}

\subsection{Inter-organizational networks in public policies in view of clusters development}

"The term network derives from the Latin word rete, which means interwoven threads, cords, string, or wire with regular openings secured with a net, forming a type of cloth" (FISCHER; MELO, 2004: 21). Thus, according to Lazzarini (2008: 2), "a network is a collection of people or companies (known technically as "us"), interlinked by means of the most diverse types of relationships (links)".

For a series of reasons, including the advances and most profound changes that have occurred in the economy and in society in general, which favor forms of organizational networks, "the present trend for network government is much broader, as well as of an entirely different kind, than any other endeavor seen previously" (GOLDSMITH; EGGERS, 2006, p. 24).

The emergence of the concept of networks in the context of current public administration, a process that was intensified during the 90s, revealed the deficiencies that existed in a series of traditional theoretical approaches which, when applied to the various dimensions of State actions, sought to understand and explain 
DOI: 10.14807/ijmp.v7i3.472

the standards of behavior of the actors involved. Once such paradigms no longer offered convincing explanations when compared to new standards of organization, which are marked by a growing fragmentation and interdependence of organizational and inter-relations formats, the concept of networks began to be seen as a more promising line to adopt, in essence because this provided a more appropriate theoretical basis with which to describe and analyze these new elements.

Thus, "literature about public administration shows the emergence of a new paradigm of public management, based on the concept of networks as a response to the process of transformation undergone by the State structure and its relationship with civil society" (FLEURY; OUVERNEY, 2007: 40).

Vázquez-Barquero (2005) states that one of the central objectives of the Government's development policy is the support to the process of continuous improvement of the territorial organization and business capacity. In addition, according to Castanhar (2005), an additional and specific challenge to improve the chance of success of the big government policies is to invest in corporate training through policies appropriated and directed to such.

Within the framework of public policies of development, according to VázquezBarquero (1995), both strategies like the actions take on a different form in each local development experience. The analysis of efforts to the creation of enterprises, the promotion of technological change or the technical training - all key actions on realization of the strategy - shows the complexity of this type of policy.

In this sense, modern economy, based on knowledge and innovation, confers a substantive function to organizational agglomerates (clusters), which has meant that policy makers have had to find new concepts of public intervention in regional areas, so as to meet - from new standpoints - the challenges of regional development based on agglomerates (WITTMANN et al., 2004).

The existence of agglomerates presupposes networks, which enable resources to be shared, that can be technological, financial, human, information knowledge or any other elements of interest to those involved, at different levels of participation. These partnerships can become effective - by means of formal or informal agreements -, and will develop based on the predisposition shown by two or more individuals, organizations or institutions so as to enjoy the benefits of the 
results obtained, based on the actions or production of each party that shares this same link of commitment and trust.

According to Wittmann et al. (2004), in order to form productive networks, the companies that form part of this agglomerate, have to cooperate amongst themselves with the purpose of gaining competitive advantages and carrying out joint actions together, that would otherwise be difficult or impossible for one company to perform on its own. "These circumstances lead to joint ventures, organizational networks, Local Production Arrangements (APLs/LPAs) or clusters, local systems of innovation and production (LSI/P), industrial areas, territorial agreements and other interactive initiatives" (WITTMANN, 2004, p. 23).

According to Paim (2005), inter-organizational networks have become the principle tools used to promote regional development. The author highlights the following as being the main tools employed: inter-municipal consortiums, citizen forums, regional chambers, regional development agencies, sectorial chambers, clusters or Local Productive Arrangements (LPAs), public interest organizations (OSCIPs), and public-private partnerships (PPPs).

Casarotto Filho and Pires (2001) cite productive agglomerations as being: productive chains, clusters, competitive agglomerations, consortiums, local economic systems and company networks. Even so, they prefer to qualify these as being simply micro and macro networks. A micro network is an association of companies whose aim is to guarantee competitiveness of the group as a whole as is the case, for instance, of a consortium. A macro network is an association which, by using mechanisms of integration involving all representative bodies within the region, is aimed at development.

Thus, Fischer and Melo (2004) proposed a configuration for interorganizations which are active in the development of territorial regions, a network which has three levels of complexity: the first level represents the organizations; the second, how organizational structures are articulated within networks, and the third represents the network of networks.

The organizations at the first level are (FISCHER; MELO, 2004, p. 23):

Membership organizations, government and company organizations, as well as funding agents, consultancy services, foundations, development banks and other unobtrusive organizations, that develop strategic actions in 
DOI: 10.14807/ijmp.v7i3.472

relation to their territorial region. Taking the form of programs and projects, partnerships, cooperatives, the organizations articulate on a second level: the level of networks.

Membership organizations can organize thematic networks between themselves, using different subjects, such as childhood, gender, health etc. They can also set up networks in the form of partnerships or alliances to develop programs and projects, which involve non-governmental organizations (NGOs)

The networks of networks have a higher level of complexity and can be represented by forums and consortiums associated with territorial profiles in the form of social-productive agreements and websites.

Casarotto Filho and Pires (2001) sought examples in the region that is today considered by them to be one of the most advanced in the world in terms of local development, built on a strong base of small businesses, which is the region of Emilia Romagna. The authors state that one of the reasons for the success of the small Emilia Romagna company is their business associations, the relational network of which is shown on Figure 1, with special emphasis given to small businesses associations.

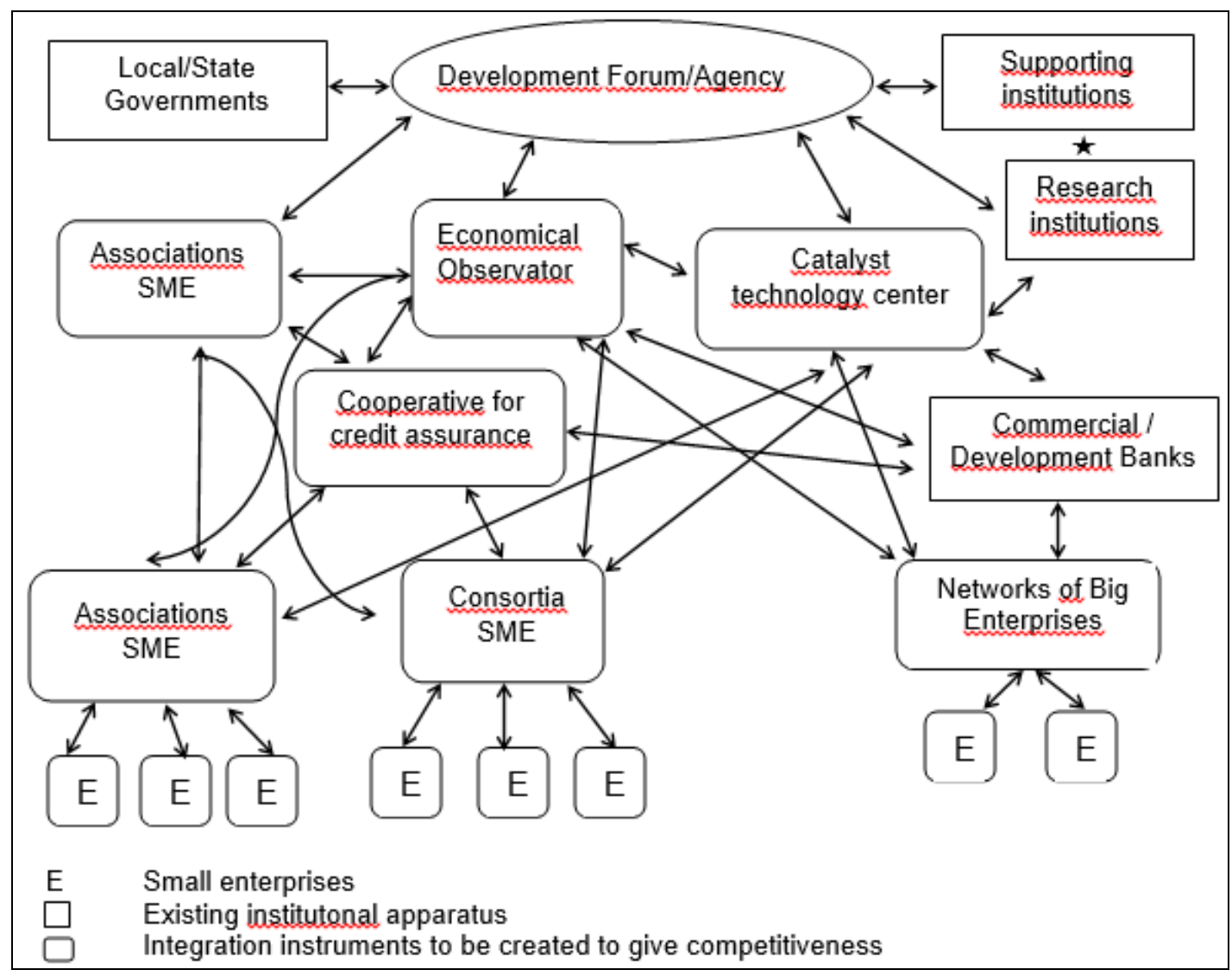

Figure 1: General model of a network - development of a local economic system focused on the association of small businesses. 
In this context, Amato Neto (2000) comments that, even though it is a wellknown fact that the experiences involved in forming cooperation networks between organizations have been diffused on a global scale since the decade of the 90s, some regions were pioneers in this aspect, as is the case of the central-northern areas of Italy, known as 'the Third Italy' (Emilia-Romagna, Vêneto and Lombardia). The first horizontal cooperation networks were established in these locations, given that these regions already provided a favorable scenario for developing linkages between small and medium-sized businesses. And, yet, to Belso-Martinez et al. (2013), with the effects of interaction between organizations is possible to organize, acquire, assimilate and explore external resources. To achieve the best performance the complementarity between internal and external resources should be promoted, because the access to external resources is a necessary, efficient condition for success.

In the debate on these new organizational formats, the dimension of human resources training appears, that is, the professional training, which has been discussed in the context of development. This question will be debated in the following section.

\subsection{Professional education as booster of clusters knowledge and development}

To Albuquerque-Llorens (2001: 77), local development "is a process of economic development and structural change that leads to an improvement in the standard of living of the local population and where various dimensions can be distinguished": environmental, economic, human resources training, administrative and socio-political. Regarding the dimension for the educational aspect, there is the training of human resources, in which the educational and training actors negotiate the adequacy of the supply of knowledge innovation requirements of local productive profiles with the local entrepreneurs.

In the context of networks of institutions that cooperate for local development Castanhar (2005), warns that, by means of agreements with educational institutions and with the financial institutions themselves, decentralized training programs of short duration, and with calendar that allows entrepreneurs to combine the program 
DOI: 10.14807/ijmp.v7i3.472

with their professional activities can be offered. The program must include the essential managerial dimensions: planning; human resource management; management of information systems and technologies; marketing management; cost accounting and corporate budget; management of financial resources and logistics resource management. Thus, according to Castanhar (2006), there is government policies aimed at micro or small business, by means of SEBRAE system, including training programs.

Currently the organizational networks are essential to facilitate the exchange of ideas and participation in a global context, whose organizations become more structured groups and responsible for distributing, disseminating and promoting the use of knowledge (SAÑUDO, 2012), where both creativity as a more central position in the network of cooperation affects innovation (DEL-CORTE-LORA et al., 2015). In addition, investment in professional education also enhances the qualities locations (geographic, economic or cultural), resulting in the so desirable sustainable development. A defense work of the development of a public policy for the creation of cluster becomes important; this is a way to reduce regional social inequalities by creating new and consistent regional circles of development in regions that remained without prospects for growth, unproductive and poor and, in this context, professional education, which for the purposes of this article focuses on preferably the technology courses provide productive viability of economic activities through know-how (FOGUEL; NORMANHA FILHO, 2007).

To Pacheco, Mesquita and Dias (2015), it is important to note that it is not enough that needs are detected and public policies are immediately implemented in order to remedy them or minimize them. It is necessary the measurement and constant monitoring of the evolution of its effective quality with regard to the services provided by their actors (teachers, administrative technicians, managers etc.) and, finally, the perception of the quality of these services by its customers (students), as occurs in private higher education institutions. By the way, the understanding of the perceptions of consumers, in case students, emerges as an important element in the process of evaluation of the Federal Institutions due mainly to their own peculiarities and, therefore, the measurement of the performance of different attributes must necessarily involve the perception their main users. Pacheco at al. (2015), approach on professional education in degree courses and Government's concern on 
INDEPENDENT JOURNAL OF MANAGEMENT \& PRODUCTION (IJM\&P) http://www.ijmp.jor.br

v. 7, n. 3, July - September 2016

ISSN: 2236-269X

DOI: 10.14807/ijmp.v7i3.472

professional and technological quality. The higher education sector in Brazil, considered the provision of services, has been explored in academic studies. Since most educators in this area, come out of the Academy without a practical experience, the strength of the formation comes from the theoretical part, requiring a greater connection with the world of work and it's about that context, with demand growth and the increase in the provision of places for students in higher education that the concern with quality in the provision of the service offered by higher education institutions (HEIs) grows. In this context, according to Davok (2007), during the last few years, Governments have shown concern about the quality of education through their public policies.

A quite current approach is made by Dias, Cardoso and Hoffmann (2014), when it issues the lack of equality in the distribution of investment in different regions of Brazil, and the privilege made some areas at the expense of others, has caused a process of uneven development across the country. Regional inequalities were pronounced and replicated within a cycle of impoverishment, resulting in the stagnation of the economy and low levels of social well-being for some regions that coexist alongside areas that are extremely dynamic in socioeconomic terms, thus forming a pattern of social inequality and lack of opportunities. In this sense, the authors confirm that the Brazilian Ministry of Education (MEC) is also involved in the intervention process, using a policy of extension created by the Federal Network of Professional Education, Science and Technology, which, in addition to conducting field research and extension, also offers professional and technical training courses, postgraduate education and technical programs in accordance with regional demands across the country. One of its main goals is to provide encouragement and support to educational processes that generate employment, income and citizen empowerment in the perspective of local and regional social economic development.

In Brazil, one of the great advances over these last years, was the creation of the Federal Network of Professional and Technological Education and the Federal Institutions (IFs) that spread throughout all national territory and answer to the need of the definitive institutionalization of the Professional and Technological Education (EPT) as a public policy. According to Haddad (2008), on this unprecedented expansion, the proposal of the Federal Institutes of Education, Science and Technology (IFs) as models of reorganization of the federal institutions of 
DOI: 10.14807/ijmp.v7i3.472

professional and technological education for a performance integrated and referenced regionally demonstrates very clearly the desirable links between systemic education, development and territoriality. According to the design material and guidelines of the federal institutes, of the Professional and Technological Education Secretariat (Setec), of the Ministry of Education (MEC), while public policy, Federal Institutes assume the role of agents employees in structuring public policies for the region that polarized, establishing a more direct interaction with the public authorities and local communities (BRASIL , 2010).

\section{METHODOLOGICAL ASPECTS}

As for the methodology, it is a descriptive research that, regarding the means, documental and bibliographic research was used.

According to Vergara (2007), the descriptive research exposes characteristics of a given population or phenomenon. It can also establish correlation between variables and define their nature. There's no commitment to explain the phenomenon it describes, although form the basis for such explanation. In this sense, it described the economic sectors in the Federal District and the professional education in Brazil. Furthermore, as to the means, the bibliographical and documental research helped of a systematic study based on material published in books and scientific magazines and data from Brazilian research institutes.

The data analyzed were collected by means of data from research done by the Instituto Brasileiro de Geografia Estatística (IBGE), namely: i) Table of Gross Domestic Product of Large Regions and Units of the Federation - 2002-2012; ii) Table of Participation of Large Regions and Units of the Federation; iii) Table of Participation of Economic Activities in the gross added value at basic prices, by Units of the Federation - 2002-2012; and iv) Pesquisa Nacional por Amostra de Domicílio (PNAD) from 2001 to 2012. These data allowed the investigation of the main jobcreating economic segments, both in the Federal District as in Brazil level.

The Pesquisa Nacional por Amostra de Domicílio (PNAD) is a sample survey that has multiple purposes, investigates various social economic characteristics of society, such as population, education, work, income, housing, social security, migration, fertility, marriage, health, etc., among other themes that are included in the 
INDEPENDENT JOURNAL OF MANAGEMENT \& PRODUCTION (IJM\&P)

DOI: 10.14807/ijmp.v7i3.472

search according to the needs of information for Brazil. We used these data to extract an analysis of data on professional education in Brazil.

Finally, regarding the treatment of the data, the tools used were SPSS and Excel to aid in the generation of descriptive statistics analysis with the frequencies of the economic sectors of Brazil and the Federal District and also within the framework of professional education, technical and technological undergraduate courses, organizing the information about the reasons of avoidance, duration and mainly, professional areas of technical courses and degrees of technology in a comparative way with the most active economic sectors.

\section{RESULTS ANALYSIS AND DISCUSSIONS}

\subsection{Federal Economical Sector in Brazil and Federal District}

The participation of the economic activities in Brazil and Federal District is shown in Tables 1 and 4, as well as the participation of the Federal District in Gross Domestic Product (GDP) in Tables 1 and 4, and Brazil and Federal District's GDP from 2002 to 2012 (Tables 2 and 3).

Table 1: Participation of the economic activities in the gross added value at basic prices by Units of Federation - 2002-2012

\begin{tabular}{|c|c|c|c|c|c|c|c|c|c|c|c|}
\hline \multirow{2}{*}{ Economic Activities } & \multicolumn{11}{|c|}{ Participation in the gross added value at basic prices (\%) } \\
\hline & 2002 & 2003 & 2004 & 2005 & 2006 & 2007 & 2008 & 2009 & 2010 & 2011 & 2012 \\
\hline \multicolumn{12}{|l|}{ Brazil } \\
\hline Total & 100.0 & 100.0 & 100.0 & 100.0 & 100.0 & 100.0 & 100.0 & 100.0 & 100.0 & 100.0 & 100.0 \\
\hline Farming & 6.6 & 7.4 & 6.9 & 5.7 & 5.5 & 5.6 & 5.9 & 5.6 & 5.3 & 5.5 & 5.3 \\
\hline Industry & 27.1 & 27.8 & 30.1 & 29.3 & 28.8 & 27.8 & 27.9 & 26.8 & 28.1 & 27.5 & 26.0 \\
\hline Mining Industry & 1.6 & 1.7 & 1.9 & 2.5 & 2.9 & 2.3 & 3.2 & 1.8 & 3.0 & 4.1 & 4.3 \\
\hline Processing Industry & 16.9 & 18.0 & 19.2 & 18.1 & 17.4 & 17.0 & 16.6 & 16.6 & 16.2 & 14.6 & 13.0 \\
\hline Civil Construction & 5.3 & 4.7 & 5.1 & 4.9 & 4.7 & 4.9 & 4.9 & 5.3 & 5.7 & 5.8 & 5.7 \\
\hline $\begin{array}{l}\text { Production and } \\
\text { distribution of } \\
\text { electricity and gas, } \\
\text { water, sewage and } \\
\text { urban cleaning }\end{array}$ & 3.3 & 3.4 & 3.9 & 3.8 & 3.8 & 3.6 & 3.1 & 3.1 & 3.2 & 3.1 & 3.1 \\
\hline
\end{tabular}

\begin{tabular}{|c|c|c|c|c|c|c|c|c|c|c|c|}
\hline Services & 66.3 & 64.8 & 63.0 & 65.0 & 65.8 & 66.6 & 66.2 & 67.5 & 66.6 & 67.0 & 68.7 \\
\hline Trade & 10.2 & 10.6 & 11.0 & 11.2 & 11.5 & 12.1 & 12.5 & 12.5 & 12.5 & 12.6 & 12.7 \\
\hline $\begin{array}{l}\text { Transports, storage } \\
\text { and courier }\end{array}$ & 4.8 & 4.7 & 4.7 & 5.0 & 4.8 & 4.8 & 5.0 & 4.8 & 5.0 & 5.1 & 5.4 \\
\hline Information Services & 3.6 & 3.6 & 3.8 & 4.0 & 3.8 & 3.8 & 3.8 & 3.6 & 3.2 & 3.0 & 2.9 \\
\hline $\begin{array}{l}\text { Financial } \\
\text { intermediation, } \\
\text { insurance and } \\
\text { supplementary }\end{array}$ & 7.5 & 7.1 & 5.8 & 7.1 & 7.2 & 7.7 & 6.8 & 7.2 & 7.5 & 7.4 & 7.2 \\
\hline
\end{tabular}


INDEPENDENT JOURNAL OF MANAGEMENT \& PRODUCTION (IJM\&P)

http://www.ijmp.jor.br

v. 7, n. 3, July - September 2016

ISSN: 2236-269X

DOI: 10.14807/ijmp.v7i3.472

insurance and related

services

\begin{tabular}{|c|c|c|c|c|c|c|c|c|c|c|c|}
\hline $\begin{array}{l}\text { Real estate and } \\
\text { rentals }\end{array}$ & 10.2 & 9.6 & 9.1 & 9.0 & 8.7 & 8,5 & 8.1 & 8.4 & 7.8 & 7.9 & 8.2 \\
\hline $\begin{array}{l}\text { Administration, public } \\
\text { health and education, } \\
\text { and social insurance }\end{array}$ & 15.5 & 15.1 & 14.7 & 15.0 & 15.3 & 15,5 & 15.8 & 16.3 & 16.2 & 16,3 & 16.6 \\
\hline Other services & 14.6 & 14.0 & 13.8 & 13.8 & 14.5 & 14,2 & 14.1 & 14.7 & 14.3 & 14.5 & 15.7 \\
\hline
\end{tabular}

In Brazil it is observed that the main economic activities are concentrated in the service sector (68.7\%), with emphasis on trade. This segment has been declining during the period from 2002 to 2004, however, grew in the following years, reaching an increase of 5.7\%; then, emerging in second place appears the industry (26.00\%), this is a sector that has been growing in the period from 2002 to 2004, when it started to face difficulties and has been dropping every year, accumulating approximately 4\% drop from 2004 to 2012; the sectors that appear then are administration, health, public education and social insurance (16.6\%) and other services (15.7\%), each of which has a slight economic growth, throughout these ten years.

Table 2: Participation of Units of Federation in the Gross Domestic Product in Brazil

\begin{tabular}{c|c|c|c|c|c}
\hline \multirow{2}{*}{$\begin{array}{c}\text { Large Regions } \\
\text { and Units of the }\end{array}$} & \multicolumn{5}{|c}{ Participation in the Gross Domestic Product (\%) } \\
\cline { 2 - 6 } & 2008 & 2009 & 2010 & 2011 & 2012 \\
\hline Federal District & 3.9 & 4.1 & 4.0 & 4.0 & 3.9 \\
\hline
\end{tabular}

Source: IBGE (2014), in partnership with the State Statistical Agencies, State departments of Government and Superintendence of the Manaus Duty Free Zone-SUFRAMA

Moreover, according to Table 2, the Federal District presented a rate of 3.9\% of real GDP growth in 2012. In addition, Table 3 shows that with value estimated at $\mathrm{R} \$ 117,326$ million, it had the reduction of 0.1 percentage point in Brazilian GDP compared to 2011.

Table 3: Gross Domestic Product in Units of Federation- 2002-2012

\begin{tabular}{|c|c|c|c|c|c|c|}
\hline \multirow{2}{*}{$\begin{array}{l}\text { Large Regions } \\
\text { and Units of } \\
\text { Federation } \\
\end{array}$} & \multicolumn{6}{|c|}{ Gross Domestic Product (1 $000000 \mathrm{R} \$$ ) } \\
\hline & 2002 & 2003 & 2004 & 2005 & 2006 & 2007 \\
\hline Brazil & $1,477.822$ & $1,699.948$ & $1,941.498$ & $2,147.239$ & $2,369.484$ & $2,661.345$ \\
\hline Federal District & 56,138 & 63,105 & 70,724 & 80,527 & 89,629 & 99,946 \\
\hline \multicolumn{2}{|c|}{ Years (continue) } & 2008 & 2009 & 2010 & 2011 & 2012 \\
\hline \multicolumn{2}{|c|}{ Brazil } & $3,032.203$ & $3,239.404$ & $3,770.085$ & $4,143.013$ & $4,392.094$ \\
\hline \multicolumn{2}{|c|}{ Federal District } & 117,572 & 131,487 & 149,906 & 164,482 & 171,236 \\
\hline
\end{tabular}


DOI: 10.14807/ijmp.v7i3.472

Source: IBGE (2014), in partnership with the State Statistical Agencies, State departments of Government and Superintendence of the Manaus Duty Free Zone-SUFRAMA

In terms of Participation of the Units of Federation in the Gross Domestic Product between 2002 and 2012, it was of 4\%, however it kept as the 7th major national GDP in 2012. In the period (2002-2012), it presented an increasing volume, $32,8 \%$.

Furthermore, according to Table 4, the services, which take part with $94 \%$ in the economy of the Federal District in 2012, having as main economic segment administration, health, public education and social insurance $(55,2 \%)$, other services $(11,3 \%)$ and financial intermediation, insurance and supplementary insurance and related services (10\%), this is because it is the seat of the federal government, where are installed the headquarters of the leading government agencies, also, has a small territorial strip, which makes insignificant other economic segments, such as agribusiness and industries.

Table 4: Participation of economic activities in the gross added value at basic prices, by Units of the Federation - 2012

\begin{tabular}{lc}
\hline \multicolumn{1}{c}{ Economic Activities } & $\begin{array}{c}\text { Participation in the gross } \\
\text { added value at basic prices } \\
\text { Total }\end{array}$ \\
\hline Farming & Federal District \\
Industry & $\mathbf{1 0 0 . 0}$ \\
Mining industry & $\mathbf{0 . 3}$ \\
Processing industries & $\mathbf{5 . 7}$ \\
Civil construction & 0.0 \\
Production and distribution of electricity and gas, water, & 1.5 \\
sewage and urban cleaning & 3.4 \\
Services & 0.7 \\
Trade & \\
Transports, storage and courier & $\mathbf{9 4 . 0}$ \\
Information services & 6.7 \\
Financial intermediation, insurance and supplementary & 2.3 \\
insurance and related services & 2.3 \\
Real estate and rentals & 10.0 \\
Administration, public health and education and social & 6.2 \\
insurance & 55.2 \\
Other services & 11.3 \\
\hline
\end{tabular}

Source: IBGE (2014), in partnership with the State Statistical Agencies, State departments of Government and Superintendence of the Manaus Duty Free Zone-SUFRAMA 
The agricultural activity of the State accounts for only $0.3 \%$ of its value added in 2012 in the Federal District (DF). Industrial activity, in turn, accounts for 5.7\% of the value added of the DF in 2012, highlighting the civil construction with a volume of $3.4 \%$. The industrial park of the Federal District is anchored, first and foremost, in editing and graphics and information technology, from which the public sector has become a major client, contributing to the performance of the manufacturing industry, with $1.5 \%$ of the total from the DF.

\subsection{Analysis of the professional education in Brazil}

On the method of demographic components demographic variables interact following cohorts of people over time, exposed to the levels and patterns of fertility, mortality and migration. The population projection for Brazil and for the Units of the Federation held in 2013 was used for the new weighting of the sample of 2001 to 2012 PNADs. This data were used to extract an analysis of data on professional education in Brazil.

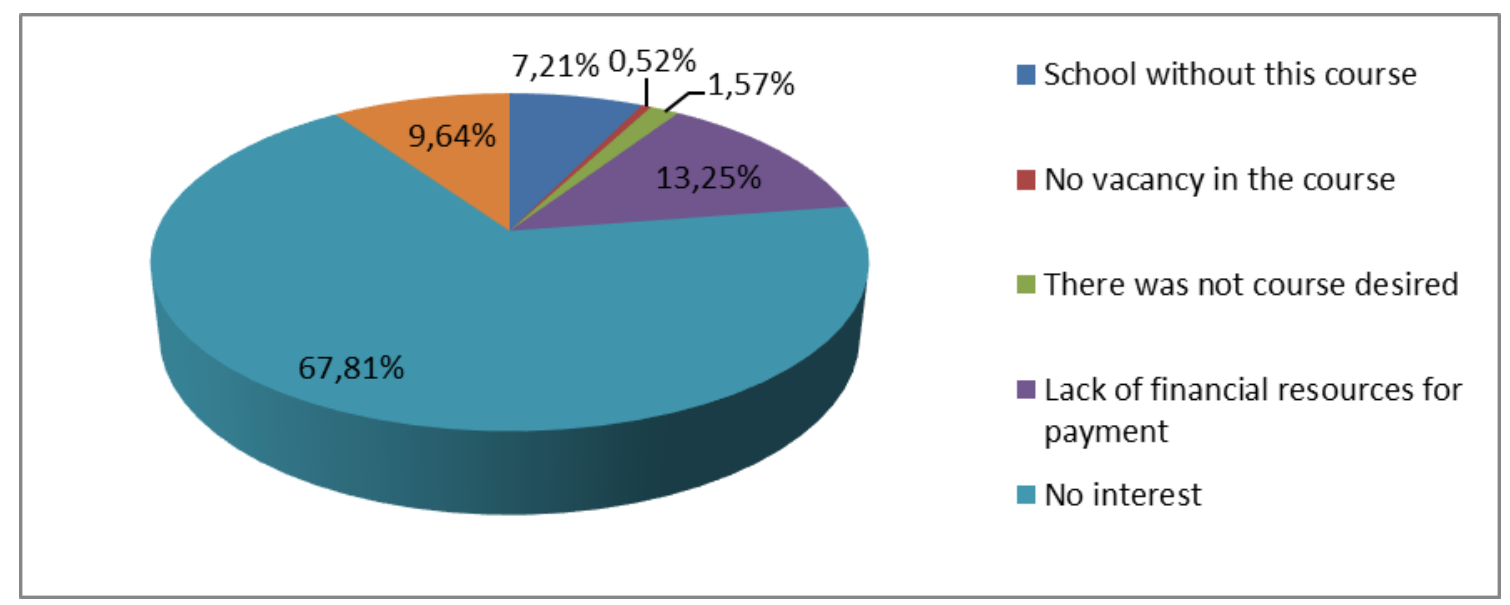

Graph 1: Reason for absence in professional course in Brazil

Despite of the unemployment and lack of qualified labor force, problems faced locally, it is noticed that the major part has not seemed interested, that can indicate a lack of the disclosure of the possibilities that those courses offer, as tool for working world, following a great percentage is absent due to lack of resources, that indicates a lack of governmental investment in order to encourage the education of a qualified labor force. 
INDEPENDENT JOURNAL OF MANAGEMENT \& PRODUCTION (IJM\&P)

http://www.ijmp.jor.br

v. 7, n. 3, July - September 2016

ISSN: 2236-269X

DOI: 10.14807/ijmp.v7i3.472

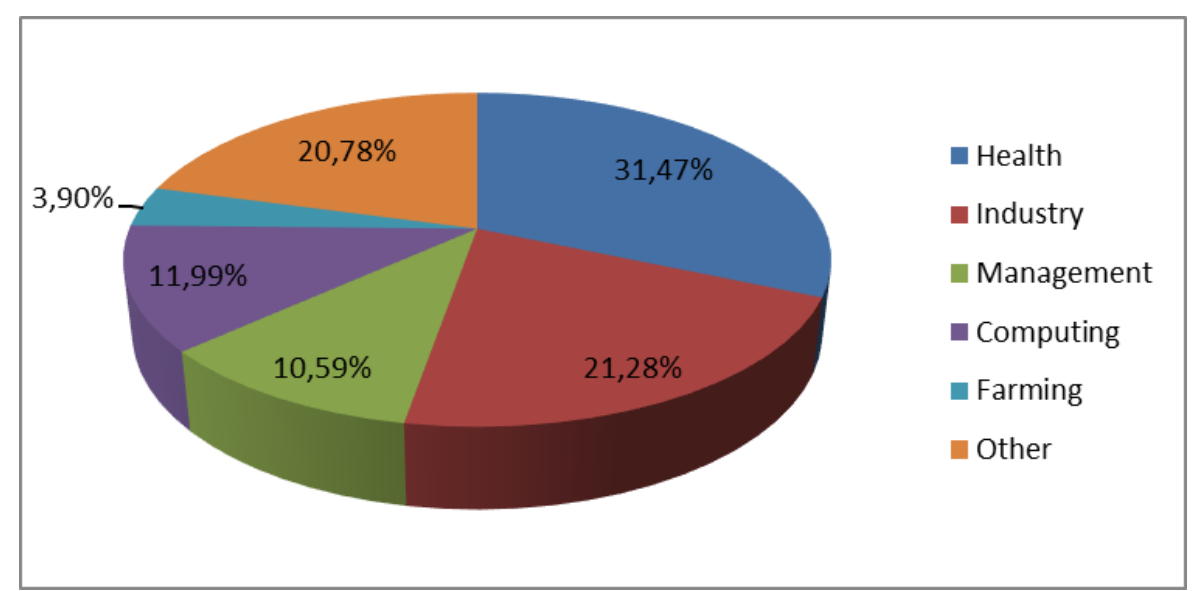

Graph 2: Professional area of technical course attended

The graph shows that the more attended technical courses are in health, industry and computing areas.

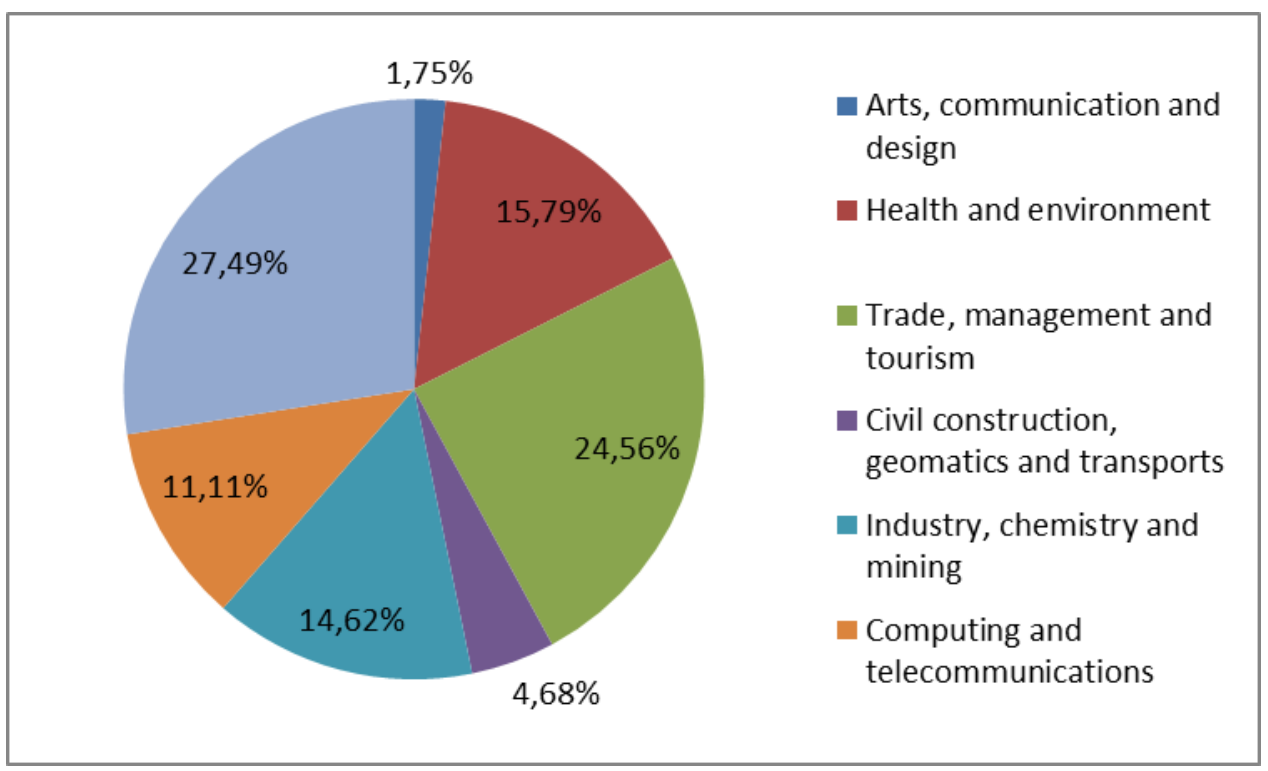

Graph 3: Professional area of the most important technological undergraduate course attended

Trade, tourism and management are the most attended areas by technological undergraduate students, on the other hand, it was noticed a significant reduction in the area of health, when compared to the mid-level technical courses. 


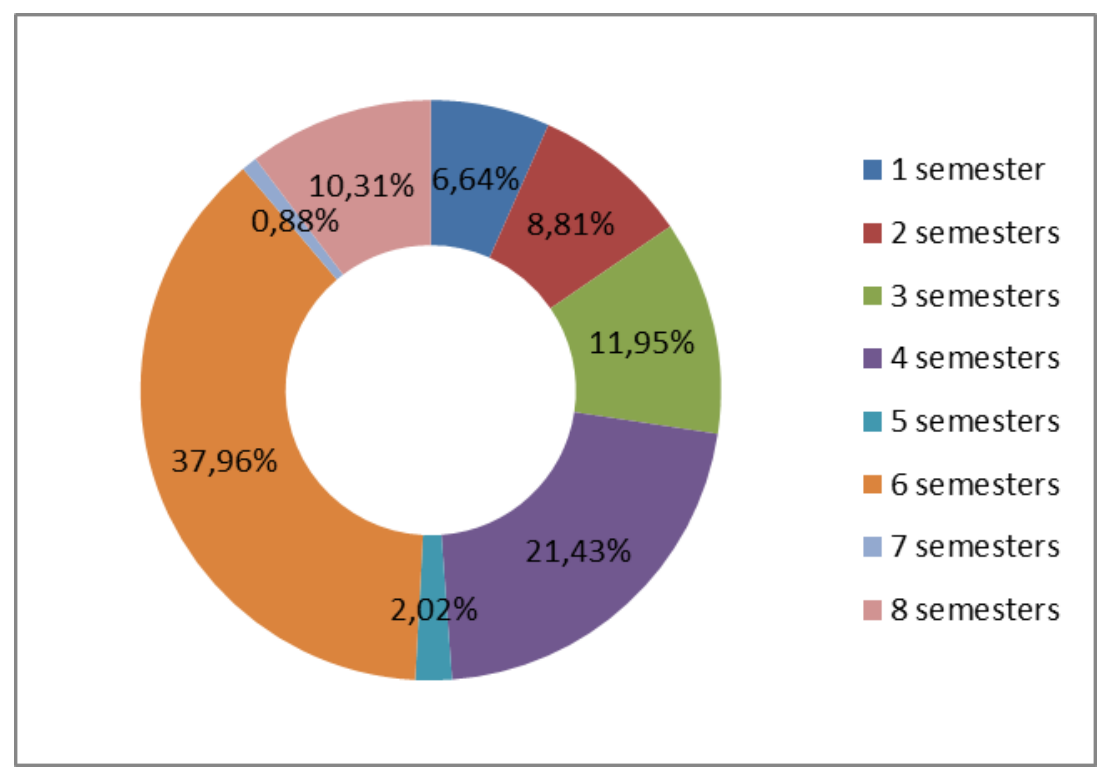

Graph 4: Mid-level technical course duration attended previously

The vast majority of people who have studied technical courses of medium level remained on that course for six semesters, time taken to acquire the technical and practical knowledge.

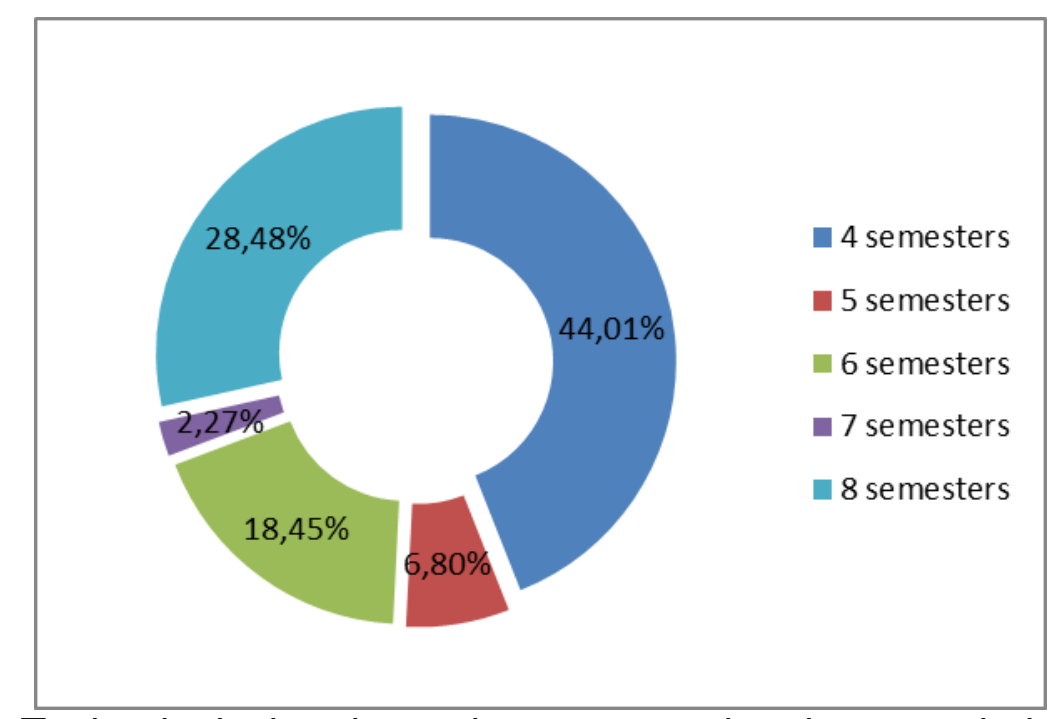

Graph 5: Technological undergraduate course duration attended previously

The majority of the technological undergraduate courses attended by the students of that segment longs four semesters, because they take part of trade and management area, where there is a strong demand, according to Table 5. 
DOI: 10.14807/ijmp.v7i3.472

Table 5: Analysis of descriptive measures of variables on professional education

\begin{tabular}{|lc|c|c|}
\hline & $\begin{array}{c}\text { Technical courses duration } \\
\text { in semesters }\end{array}$ & $\begin{array}{c}\text { Technological undergraduate } \\
\text { duration in semesters }\end{array}$ \\
\hline $\mathrm{N}$ & Validity & 11418 & 309 \\
Mean & Missing & 388546 & 399655 \\
Median & & 4.72 & 2.64 \\
Mode & 5.00 & 2.00 \\
Standard Deviation & 6 & 1 \\
Variance & 1.953 & 1.695 \\
Minimum & & 3.814 & 2.873 \\
Maximum & & 1 & 1 \\
& 25 & 8 & 5 \\
Quartiles & 50 & 3.00 & 1.00 \\
& 75 & 5.00 & 2.00 \\
& & 6.00 & 5.00 \\
\hline
\end{tabular}

Source: elaboration by author based on data from PNDA 2013

The value of mean is very close to the median values, with the length of the technical course in semesters, the mean is slightly lower than the median, showing an asymmetry to the left while in the variable duration of technology undergraduate semesters, the average is higher than the median, showing an asymmetry to the right, that is, the majority of cases is below mean. Soon, the median is an alternative to represent the central position in asymmetric distributions and both measures calculated to evaluate the central position under two approaches, as well as to get a first assessment on the asymmetry of the distribution.

In addition, facing the results of this article is stressed that services take part with $93.3 \%$ of the economy of the Federal District, in 2008, grew by $3.5 \%$ in real terms the manufacturing industries were highlighted, with growth of $9.7 \%$. Contributing to the good performance of the manufacturing industry, differences in the focus of vocational education can be noticed, according to the PNAD (2013), where most students are taking courses in the area of health, mainly mid-level courses for basic services, to the upper technological courses, demand decreases significantly. The need of enhancing those health courses is perceived.

On the other hand, according to the PNAD (2013) data, there are a significant number of students in courses in the field of industry, which is one of the fastest growing segments in the Federal District.

According to Dias, Cardoso and Hoffmann's research (2012), the network of professional education is one of the drivers for regional development. In this regard, it is noticed in the results that despite the discrepancy between the training of skilled labor, some segments have been growing considerably, but there is still lack of 
DOI: $10.14807 /$ ijmp.v7i3.472

articulation between the productive segment and the educational segment for training of workforce that meets the real needs of these segments, whose expertise in network assists professional training.

An expansion in professional training in the Federal District is the result of the creation of the Federal Institute of Brasília (IFB), a public institution that offers free Professional Education, in the form of courses and initial and continuing training programs for workers (FIC); mid-level technical courses; and technological degree course, at undergraduate and postgraduate level. The structure of several campi at IFB provides the institution with secure technology, diversifying their service, in accordance with economic vocation of the administrative regions of the Federal District.

Professional education that was offered by private institutions, Government of the Federal District and by the S system, until the year of 2008, with only a technical school in agriculture by the federal network, obtained with the creation of the IFB over 9 campi in the Federal District. Currently, the IFB is composed of a Rectory (based on Pilot Plan) and 10 campi in the Federal District: Brasilia, Ceilândia, Estrutural, Gama, Planaltina, Riacho Fundo, Samambaia, São Sebastião, Taguatinga and Taguatinga Centro, working in the various areas of professional education, with continuing education courses, technical courses, technological courses, undergraduate, degree courses and postgraduate degrees, serving a very large universe of students in professional training, within the Federal District and surroundings, where the vast majority are low-income people, which has the possibility of professional training free of charge.

\section{CONCLUSION}

This article sought to introduce concepts of networks with a focus on professional education as a catalyzer for local development. The studies carried out on bibliographical research reinforce the proposition that with a strengthening of relations between professional education and the productive segment it is possible to obtain a larger regional development. The data presented in the documents of the IBGE demonstrate economic segments that are growing and those that are decreasing their participation over the course of a decade, a flag of the real need for research and training of labor force. We analyzed the main productive segments of 
DOI: 10.14807/ijmp.v7i3.472

the Federal District and also an analysis based on national data from PNAD on professional education, which allowed a better understanding of these variables, in order to identify gaps that need to be filled.

By demonstrating inter-organizational and territorial development network, according to Fischer and Melo (2004) with new organizational formats, there is a new perspective on the generator of territory concept, discussed in the scope of development through the diverse types of organizations, productive arrangements (clusters) configuring joint projects and partnerships. Thus, according to Albuquerque-Llorens (2001), educational and training actors aim to select professional who have knowledge required by enterprises in order to boast the process of economic development and structural change, that lead to local population's life level increase, that is, this promotes cluster development. Therefore, professional education plays a great role in professional education, working as a network among clusters whose synergy between productive and professional education sectors bring the possibility of innovation in the several productive segments.

The organizations, enterprises and associations chain thematic networks among themselves, which may present themselves in the form of productive arrangements (clusters) to virtual spaces; this scenario creates a favorable environment for cooperation between small and medium-sized enterprises.

Professional education appears as a relevant element in the construction of cooperative networks, by raising the level of knowledge of the people who form the entities members of the networks, the generation of new knowledge allows a systemic vision, where factors such as productivity, economy of scale and the possibility of exchanging experiences, allow the strengthening of the development of the region.

In the analysis held in the Federal District it is noticeable the prominent economic segments, when comparing with the national graph, taking into account the peculiarity of the Federal District, that being the seat of Government, demands a lot of labor force services segment, as tables 1 and 2, so the professional education must be attuned to this demand, to provide professionals according to the vocation of the region. 
INDEPENDENT JOURNAL OF MANAGEMENT \& PRODUCTION (IJM\&P)

http://www.ijmp.jor.br

v. 7, n. 3, July - September 2016

ISSN: 2236-269X

DOI: 10.14807/ijmp.v7i3.472

The analysis performed with professional education diagnosed more professional preference for courses in the areas of health and trade. The national survey found that most people who do not attend a professional training course, doesn't have that interest. Those sectors that are more in evidence, or that there's a strong demand, are the ones who have more professionals trained on the area.

The limitation of this research is due to data collection which occurred exclusively by documental and bibliographic resources. For future research an investigation using other types of data collection, questionnaires and interviews with the professional education and productive segment is suggested, to identify remedy gaps that need to be primary data, as well as studies that search integration and cooperation between the various types of productive networks and professional education, aiming the promotion of regional development.

\section{REFERENCES}

ALBUQUERQUE-LLORENS, F. (2001). Desenvolvimento econômico local. Rio de Janeiro: BNDES.

AMATO NETO, J. (2000). Redes de cooperação produtiva e clusters regionais: oportunidades para as pequenas e médias empresas. São Paulo: Atlas.

BELSO-MARTINEZ, J. A.; MOLINA-MORALES, F. X.; MAS-VERDU, F. (2013). Combining effects of internal resources, entrepreneur characteristics and KIS on new firms. Journal of Business Research, v. 66, p. 2079-2089.

BRASIL. MINISTÉRIO DA EDUCAÇÃO (2010). Institutos Federais, um novo modelo em educação profissional e tecnológica: concepção e diretrizes. Brasília: Setec.

CASAROTO FILHO, N.; PIRES, L. H. (2001). Redes de pequenas e médias empresas e desenvolvimento regional. São Paulo: Atlas.

CASTANHAR, J. C. (2006). Arranjos Produtivos Locais como estratégia de interiorização da atividade econômica, com dinamismo e redução das desigualdades. In: FLEURY, S. (Org.). Democracia, descentralização e desenvolvimento. Rio de Janeiro: FGV.

CASTANHAR, J. C. (2005). Capacitação Empresarial. In: CAVALCANTE, B. S.; RUEDIGER, M. A.; SOBREIRA, R. (Orgs). Desenvolvimento e construção nacional: políticas públicas. Rio de Janeiro: FGV.

DAVOK, D. F. (2007). Qualidade em educação. Avaliação: Revista da

Avaliação da Educação Superior, v. 12, n. 3, p. 505-513.

DEL-CORTE-LORA, V.; VALLET-BELLMUNT, T.; MOLINA-MORALES, F. X. (2015). Be creative but not so much. Decreasing benefits of creativity in clustered firms.

Entrepreneurship \& Regional Development, v. 27, n. 1-2, p. 1-27. 
DIAS, C. N.; CARDOSO, F. M. C. B.; HOFFMANN, V. E. (2014). Inter-organizational relations for regional development: an expansion policy promoted by the federal network of professional education, science \& technology. Independent Journal of Management \& Production, v. 5, n. 4, p. 902-920.

FISCHER, T.; MELO, V. P. (2004). Organizações e interorganizações na gestão do desenvolvimento sócio-territorial. Revista Organizações \& Sociedade, v. 11, p. 1341.

FLEURY, S.; OUVERNEY, A. M. (2007). Gestão de redes: a estratégia de regionalização da política de saúde. Rio de Janeiro: FGV.

FOGUEL, F. H. D. S.; NORMANHA FILHO, M. A. (2007). Um fator de desenvolvimento de clusters no Brasil: a educação profissional. Cadernos EBAPE.BR, v. 5, n. 1, p. 1-16.

GIL, A. C. (2007). Métodos e técnicas de pesquisa social. 5. ed. São Paulo: Atlas.

GOLDSMITH, S.; EGGERS, W. D. (2006). Governar em rede: o novo formato do setor público. Brasília: ENAP.

HADDAD, F. (2008). O novo Plano de Desenvolvimento da Educação. In: Velloso, J. P. R. \& Albuquerque, R. C. A verdadeira revolução brasileira: integração de desenvolvimento e democracia. Rio de Janeiro: José Olympio.

IBGE - Instituto Brasileiro de Geografia e Estatística. Tabela 05 - Participação das atividades econômicas no valor adicionado bruto a preços básicos, por Unidades da Federação- 2002-2012. Rio de Janeiro: IBGE, 2013. Available: http://www.ibge.gov.br/home/estatistica/economia/contasregionais/2012/default_xls_ 2002_2012.shtm. Access: 01.08.2015.

IBGE - Instituto Brasileiro de Geografia e Estatística. Tabela Microdados reponderados da PNAD 2001 - 2012. Rio de Janeiro: IBGE, 2013. Available: http://www.ibge.gov.br/home/estatistica/populacao/trabalhoerendimento/pnad2012/m icrodados.shtm. Access: 11.05.2015.

IBGE - Instituto Brasileiro de Geografia e Estatística. (2012). Contas regionais do Brasil - 2012. Rio de Janeiro: IBGE, 2014. Available: http://biblioteca.ibge.gov.br/visualizacao/livros/liv89103.pdf. Acesso em 01.08.2015.

KOCHE, J. C. Fundamentos de Metodologia científica: teoria da ciência e prática da pesquisa. 14. ed. Petrópolis, RJ: Vozes.

LAZZARINI, S. G. (2008). Empresas em rede. São Paulo: Cengage Learning.

PACHECO, I. J. D.; MESQUITA, J. M. C.; DIAS, A. T. (2015). Qualidade Percebida e Satisfação dos Alunos da Rede Federal de Educação Profissional e Tecnológica.

Revista Gestão \& Tecnologia, v. 15, n. 2, p. 5-28.

PAIM, J. C. (2005). Ferramentas de desenvolvimento regional. São Paulo: El Edições Inteligentes.

SAÑUDO, L. (2012). El papel de las redes profesionales de investigación en un mundo globalizado, Revista Iberoamericana sobre Calidad, Eficacia y Cambio en Educación, v. 10, n. 3, p. 135-143. 
TRIVIÑOS, A. N. S. (1987). Introdução à pesquisa em ciências sociais: a pesquisa qualitativa em educação. São Paulo: Atlas.

VÁZQUEZ-BARQUERO, A. (1995). Desenvolvimento Local: Novas dinâmicas na acumulação e regulação do capital. Ensaios FEE, Porto Alegre, v. 16, n. 1, p. 221241.

VÁZQUES-BARQUERO, A. (2005). Las nuevas fuerzas del desarrollo. Barcelona: Antonio Bosch Editor.

VERGARA, S. C. (2007). Projetos e relatórios de pesquisa em administração. 9 ed. São Paulo: Atlas.

WILLIAMSON, O. E. (1991). Comparative Economic Organization: the Analysis of Discrete Alternatives. Administrative Science Quarterly, v. 36, p. 269-296.

WITTMAN, M. L. et al. (2004). Estruturas organizacionais em rede e desenvolvimento regional: contextualização e complexidades. In: WITTMAN, M. L. \& RAMOS, M. P. Desenvolvimento Regional: capital social, redes e planejamento. Santa Cruz do Sul: Edunisc.

ZANELLA, L.C. H. (2009). Metodologia de estudo e de pesquisa em administração. Florianópolis: UFSC; CAPES: UAB.

ZAPATA, T.; AMORIM, M.; ARNS, P. C. (2007). Desenvolvimento territorial à distância. Florianópolis: SEaD/UFSC. 